\title{
How Smartphone influences the Lifestyle of School Children and Perception of Students on Smartphone
}

\author{
Article by Roy Rillera Marzo, Ting Lik Sheng, Andrew Chiew Yung Kung \\ Deputy Dean, Asia Metropolitan University, Malaysia \\ Email: rrmtexas@yahoo.com
}

\begin{abstract}
Objectives: The general objective of this study is to determine the extent of the influences of smartphones on school children and perception of school children on smartphones. This objective is to explore the social behavior, academic performance and health aspects.

Background: Smartphone addiction, its association with smartphone use, and its predictors have not yet been studied in a Muar, Johor sample. This study investigated the influences of smartphone and the perception of school children on smartphone in social behavior, academic performance and health aspects.

Methods: The study was carried out using convenient sampling method and using cross sectional study. Three primary schools were selected in Muar district. Each school are composed of Malay, Chinese and Tamil primary school. The questionnaire distributed were composed of 30 questions which include the social demographic, social behavior, academic performance and health aspect.

Results: Over half of the school children owned a smartphone. From the social behavior aspect, 145 students disagreed with having emotional changes while away from phone. 166 students supported the idea of not extending the time spent on smartphone. Form the academic performance aspect, over half of the respondents agreed to the idea of banning the usage of smartphone in school compound. From the health aspect, 123 students experienced neck pain after using smartphone for a long time; but, only less than half of the respondents (58) agreed to the idea of smartphone causes obesity.

Conclusion: Hypothesis failed. The school children are not easily influence by the smartphone and their perception on smartphone are good, as seem in the aspect of social behavior and academic performance. However, the students have a moderate perception on smartphone from the aspect of health.
\end{abstract}

\section{Introduction}

\subsection{Introduction}

Overview: The earliest smartphone released is during the 1990's.But, of course, with such technologies, people can do things easily and with that, more and more people own smartphone. With this, data traffic from users increased drastically which will also cause the increased mobile charge or mobile bills. It is predicted that by 2020, mobile data will have covered 80 percent of mobile data traffic (Lunden, 2015). This clearly shows how the population of human is dependent on mobile phone. This will then lead to addiction to mobile phone.

There are many criteria to show mobile phone overuse in a person. In 21st century, almost all the age groups know how to operate a smartphone. Nowadays, even 2 years 
old knows how to play games and watch YouTube in his or her smartphone. Age group between 18 and 29 is the highest percentage of using smartphone (Pew Research Center, n.d.) Recently from Common Sense Media, more than one third of children under age of 2 use mobile phone which cover 38 percent of the children (Krumboltz, 2013).

\subsection{Advantages of smartphones in school children}

Smartphone had invariably provide advantages that can be used in our everyday life. With smartphone, children are able to interact with other people at the tip of their finger. They can communicate easily with other people outside their house. This allow the children to keep in touch with their parents. This is especially true in school children when there is a change in their school schedule or when there is an emergency. The rise of smartphone use can be seen in United State when there is a rise in mass school shooting. A research firm, YouthBeat, more than 1 of 10 kids between the ages of 6 to 10 own their own mobile phone (Meredith, 2012).

Others include a new and interesting dimension of learning. According PBS Parents Guide to Children \& Media, it allow them to explore the virtual reality of media which include augmented reality, dictionaries and encyclopedia. It is apart from the traditional way of teaching (Jones, 2013).

Children can also download health application (apps) in their smartphone such an app that can keep track their diet. This help them to be fit and healthy. Other than that, the inclusion of pedometer to help keep track the number of steps taken per day.

\subsection{Disadvantages of smartphones in school children}

There are also many harmful effects on the school children. The matter of contents they shown should be controlled. One of the effects is that the children are more easily exposed to pornography, cyberbullying, anorexia sites and many more. Their social interaction will be impaired in the future.

On the other hand, many consider smartphone as a distraction tools among the school children. Some of this school children abuse the smartphone that is meant as their study tools. This makes them to focus more on their smartphone rather than listening to their lecture of the day. Their academic performance will declined due to these smartphone.

Distraction not only affect individually, but also irritate others in a group or teachers. The sound or ringtone from the smartphone can affect the flow or pattern of the class. It then leads to irritability.

Other than that, the usage of smartphone by school children also make them feel sleepless and tired. They will spend the whole night playing and using the smartphone. They will had slept at 2 or 3 morning. Because of this, they cannot concentrate during the class the next day. This will cause a poor performance in the academic skills. They will not able to feel fresh and confident on the next morning.

\subsection{Significance of study}

There are of course pros and cons of school children using smartphones. With this, we will conduct a research about how smartphones affect the lifestyle of school children. This is to understand how the smartphones effect on their social 
performance, academic performance and health. The purpose of this study is also aiming to see how much perception does a child towards the smartphones.

\section{Literature review}

\subsection{Introduction}

Different aspects of lifestyle has been influenced by the invention of smartphone. Aspects such as social, health and academic performances shown to have the biggest influences by the usage of smartphone.

\subsection{Literature review}

There are several researches suggested that it has either bad or good influences. (Power MR, 2004) proposed that an opportunity is given to young people to create new and maintain relationship by the usage of mobile phone.) (al., 2003) stated that social fulfillment of youngsters such as access, convenience and mobility is provided by smartphone.(V, 2000) and (R) suggested that with this technology, busy parents can better be in touch with their children thus lessen their stress. Besides that, it is a necessity to own a smartphone by college students in order to keep in touch with their family, as stated by (al, 2011). (B, 1997) proposed that youngsters seek peer group acceptance by using their mobile phones. Contrast to these statement, there are some bad influences in the social aspect of lifestyle of youngster nowadays. A study that had been conducted by James and (James J, 2011) on Australian students concluded that there are adverse consequences of excessive usage of smartphone such as the increases in financial costs, emotional stress, damaged relationships and falling literacy. stated there is a linkage between criminal activities like alcohol, fighting, theft and narcotics use and the usage of smartphone. (L, 2005) claimed that students even use their mobile phones while attending their lectures. Griffiths and Renwick (2003) (Griffiths M, 2003) stated that being in debt and other financial worries of adolescents is one of the significances of the higher usage of mobile phone. (Thompson R, 2007) emphasized security of children using mobile phone by pinpointing the potential risks of uncontrolled expenditures, exposure and access to prohibited, damaging or adult material and bullying via mobile phone.

Basing on their acadmia, (Sánchez-Martínez, 2009) suggested that intensive cell phone use was related to school failure as well as other negative behaviors such as smoking and excessive alcohol use. Several studies reveal that students frequently report using a variety of electronic media including cell phones while in class, studying, and doing homework (Jacobsen, 2011) (W, 2012) (Junco, 2012) (Junco, Too much face and not enough books: the relationship between multiple indices of facebook use and academic performance, 2012) (Junco R. a., 2012) (Wood, 2012).First, measured the influence of multitasking with an array of electronic media on students' ability to learn from typical, university classroom lectures. Emailing, MSN messaging, and Facebook use via computer were all investigated as was cell phone texting. Results showed that multitasking with any of the technologies was associated with lower scores on follow up tests compared with students who did not multitask.

Immense research had been made from the effects of smartphone on smartphone. (EJ, 2003) finds out that most of the students from United States are inclined to make calls at night which can lead to some adverse outcomes such as sleep loss. Niaz (U, 
South American Journal of Academic Research

Volume 3, Issue 1, 2016

2008) proposed that an awareness about the dangers associated with excessive and addictive mobile use must be created among the society because a public health problem have appeared due to unwise usage of smartphone. (James J, 2011) Highlighted some adverse consequences of excessive usage of smartphone, such as the financial costs, emotional stress, damaged relationships and falling literacy.

In conclusion, a study has to be done on this matter in order to create an awareness on the influence of smartphone on the lifestyle of school children.

\subsection{Objectives}

The general objective of this study is to determine the extent of their perception of school children on smartphones and the influences of smartphones on school children. In order to achieve the objective, three ideas are generated, they are:-

1. To determine the influence of smartphone and the perception of school children on smartphone from social behavior aspect of school children.

2. To determine the influence of smartphone and the perception of school children on smartphone from academic aspect of school children.

3. To determine the influence of smartphone and the perception of school children on smartphone from health aspect of school children.

\subsection{Hypothesis}

The school children are easily influence by the smartphones and have bad perception on the effect of smartphone on the aspects of social behavior.

The school children are easily influence by the smartphones and have bad perception on the effect of smartphone on the aspects of health.

The school children are easily influence by the smartphones and have bad perception on the effect of smartphone on the aspects of health.

\section{Methodology}

\subsection{Study design}

The study approach for this research is quantitative approach study and crosssectional study. These data were then collected to be analyzed descriptively. The target population of this study are students ranging from Standard 4, Standard 5 and Standard 6 in

- $\quad$ SK ParitSetongkat

SJK (C) Chung Hwa No 2A and No 2B

- $\quad$ SJK (T) JalanKhalidi

The data will be collected through the method of convenient sampling.

\subsection{Sample population}

All students ranging from Standard 4, Standard 5 and Standard 6 were encouraged to participate in this study provided that they are from

a. SK ParitSetongkat

b. SJK (C) Chung Hwa No 2A dan No 2B

c. SJK (T) JalanKhalidi 


\subsection{Sampling method}

The research were conducted using a non-probability sampling. The sampling method was convenient sampling. This method was carried out by choosing 3 primary schools, where 1 Malay primary schools, 1 Chinese primary school and 1 Tamil primary schools. Students from Standard 4, Standard 5 and Standard 6 are all chosen from each school. The schools are selected when the headmaster gives the permission to conduct the survey. The data would be collected and analyzed.

\subsection{Survey instrument}

A questionnaire were distributed in 3 different primary schools, whereby 1 from Malay primary school, 1 from Chinese primary school and 1 from Tamil primary school, for the purpose of data collection in this study. The questionnaire distributed were to target on standard 4, standard 5 and standard 6 students. The answered questionnaire were collected after completion on the spot itself.

\subsection{Questionnaire design}

The questionnaire created were adapted from a few sources (Min Kwon, 2013) but mostly were created by us. We were to run pre-test to validate the questionnaire. The validation are to be done by our research supervisor Dr. Roy. The questionnaire are divided into 4 parts, namely, their socio- demographic part with questions associated with general perception on smartphone, the social behavior aspect, the academic aspect and the health aspect.

\subsection{Data analysis}

The primary data analysis will be coded and analyzed by PASW Statistics Student Version 18. Descriptive statistics were used to describe the demographic features of the participants and tables with frequency and percentages will be used to interpret the results.

\subsection{Ethical consideration}

The protocol were required to review by the Medical Research Ethical Committee (MREC) of Asia Metropolitan University to insure full protection of the rights of study subjects. NMRR (National Malaysian Research Register) registration will be carried out after the approval by MREC. Following the acquisition of NMRR registration number, the questionnaires were distributed to the study subjects. To assure the confidentiality of all the information provided, a cover letter will be attached with the questionnaire.

\section{Result and discussion}

Table 1. Sociodemographic Data

\begin{tabular}{|c|c|c|c|}
\hline \multicolumn{3}{|c|}{ Variables } & \multicolumn{2}{c|}{ Frequency (n), Percentage (\%) } \\
\cline { 3 - 4 } & Male & With smartphone & $\begin{array}{c}\text { Without } \\
\text { smartphone }\end{array}$ \\
\hline \multirow{2}{*}{ Gender } & Female & $42(57.4)$ & $46(42.6)$ \\
\cline { 2 - 4 } & 10 & $43(44.3)$ & $60(55.6)$ \\
\hline Age & \multicolumn{2}{|c}{$54(55.67)$} \\
\hline
\end{tabular}


South American Journal of Academic Research

Volume 3, Issue 1, 2016

\begin{tabular}{|c|c|c|c|}
\hline & 11 & $42(60.86)$ & $27(39.14)$ \\
\hline & 12 & $25(50)$ & $25(50)$ \\
\hline \multirow{3}{*}{$\begin{array}{c}\text { Type of Primary } \\
\text { School }\end{array}$} & Malay Primary School & $35(40.7)$ & $51(59.3)$ \\
\hline & Chinese Primary School & $54(67.5)$ & $26(32.5)$ \\
\hline & Tamil Primary School & $21(42)$ & $29(58)$ \\
\hline \multirow{4}{*}{ Race } & Malay & $40(44)$ & $51(56)$ \\
\hline & Chinese & $48(66.7)$ & $24(33.3)$ \\
\hline & Indian & $21(40.4)$ & $31(59.6)$ \\
\hline & Others & $1(100)$ & $0(0)$ \\
\hline \multirow{3}{*}{$\begin{array}{l}\text { Age of having } \\
\text { Their First } \\
\text { Smartphone }\end{array}$} & $<7$ Years Old & $20(90.9)$ & $2(9.1)$ \\
\hline & 8-12 Years Old & $82(91.1)$ & $8(8.9)$ \\
\hline & Do Not own Smartphone & $8(7.7)$ & $96(92.3)$ \\
\hline \multirow{3}{*}{ Parents’ Income } & $<$ RM2500 & $48(51.1)$ & $46(48.9)$ \\
\hline & RM2500-RM4000 & $34(55.7)$ & $27(44.3)$ \\
\hline & $>$ RM4000 & $28(45.9)$ & $33(54.1)$ \\
\hline \multirow{4}{*}{$\begin{array}{l}\text { Perception on time } \\
\text { spend on } \\
\text { Smartphone }\end{array}$} & $<2$ hours & $58(46)$ & $68(54)$ \\
\hline & 2-3 hours & $23(50)$ & $23(50)$ \\
\hline & 3-5 hours & $15(62.5)$ & $8(34.8)$ \\
\hline & $>5$ hours & $14(66.7)$ & $7(33.3)$ \\
\hline \multirow{4}{*}{$\begin{array}{l}\text { Perception on the } \\
\text { types of apps } \\
\text { preferred they } \\
\text { preferred most }\end{array}$} & Social Media & $22(61.1)$ & $14(38.9)$ \\
\hline & Education & $15(38.5)$ & $24(61.5)$ \\
\hline & Entertainment & $63(54.8)$ & $52(45.2)$ \\
\hline & Others & 10 (38.5) & $16(61.5)$ \\
\hline \multirow{2}{*}{$\begin{array}{l}\text { Perception on } \\
\text { usefulness of } \\
\text { smartphone }\end{array}$} & Yes & $101(59.1)$ & $70(40.9)$ \\
\hline & No & $9(20)$ & $36(80)$ \\
\hline
\end{tabular}

In this research, we have the total of 216 participants, while 110 (male, 62; female, 48) of the respondents are using smartphone. According to this data, we can see that there are more male students using smartphone than female. To support our finding, (al D.-D. J., 2008/2009) stated that the boys spent more time on smartphone compared to the girls. On the contrary, there are researches such as (al m. h., 2011), suggested that females, especially whites, were more likely to depend heavily on their phones to maintain social relationships.

We conclude that regardless of age, there are more students using smartphone at the age of 10; compared to the age of 11 and 12 with the lesser number of students using smartphone. But, if we compare the percentages, most of the 11 years old students (60.86\%) own a smartphone.

Compare between races, Chinese have the highest number of students who are using smartphone. Then, it comes to Malay with (40\%) and Indian (21\%).

Regardless of family income, there are more students from lower income family using smartphone compared to the middle income family (34\%) and the higher income family (28\%). This statement is supported by (al B. K., 2011) found that lower income students used their mobile phones more and majority of the respondents are spend most of the time in smart phone for less than 2 hours. 
In the application aspects, most students (115\%) prefer to use smartphone as an entertainment devices. Nevertheless, education application is another popular choice for students (39\%) which has higher percentage compared to social media. This is very different from what (al. L. K., 2015) have found in their study. They found that most of the students in higher learning institutions tends to use smartphones for social related purposes than academic purpose.

Table 2. Social Behavior Data

\begin{tabular}{|c|c|c|c|}
\hline \multirow[t]{2}{*}{ Types of Aspects } & \multirow[t]{2}{*}{ Items } & \multicolumn{2}{|c|}{$\begin{array}{c}\text { Frequency (n), Percentage } \\
(\%)\end{array}$} \\
\hline & & Yes & No \\
\hline \multirow{2}{*}{ Influences } & $\begin{array}{l}\text { Did you ever use smartphone } \\
\text { in the presence of your family } \\
\text { or friends? }\end{array}$ & 129 (59.7) & 87 (40.3) \\
\hline & $\begin{array}{l}\text { Did your family or friends } \\
\text { told you that you spend a lot } \\
\text { of time on your smartphone? }\end{array}$ & 107 (49.5) & 109 (50.5) \\
\hline \multirow{4}{*}{ Perception } & $\begin{array}{l}\text { Do you think you will get } \\
\text { nervous, moody and } \\
\text { depressed while away from } \\
\text { cell phone? }\end{array}$ & 71 (32.9) & 145 (67.1) \\
\hline & $\begin{array}{l}\text { Will you spend more time on } \\
\text { smartphone when you are } \\
\text { attending an event such as } \\
\text { wedding or at a beach? }\end{array}$ & $50(23.1)$ & 166 (76.9) \\
\hline & $\begin{array}{l}\text { Do you think smartphone is a } \\
\text { better communication tools } \\
\text { than meeting people face to } \\
\text { face? }\end{array}$ & $109(50.5)$ & 107 (49.5) \\
\hline & $\begin{array}{l}\text { Do you think there is a need to } \\
\text { increase the time spent in your } \\
\text { smartphones even when you } \\
\text { used for long time? }\end{array}$ & $68(31.5)$ & 148 (68.5) \\
\hline
\end{tabular}

With regards to influences of smartphone, most of the respondents (59.7\%) use smartphone in the presence of their family and friends and almost 50\% said by their friends and family that they spent a lot of time in their smartphone.

Most of the school children (67.1\%) disagreed on emotional changes while they are away from the cell phone. This statement is contrary to the opinion of (Archer, 2013) where Archer suggested smartphone users will easily get annoyed when they are unable to access to smartphone. Besides that, $76.9 \%$ of the school children disagree to spend more time on smartphone when they are attending an occasion. Other than that, $68.5 \%$ of school children do not support the act of extending the time period on smartphone. 
South American Journal of Academic Research

Volume 3, Issue 1, 2016

Table 3. Academic Performance Data

\begin{tabular}{|c|c|c|c|}
\hline \multirow[t]{2}{*}{ Aspects } & \multirow[t]{2}{*}{ Items } & \multicolumn{2}{|c|}{$\begin{array}{l}\text { Frequency (n) } \\
\text { Percentage (\%) }\end{array}$} \\
\hline & & Yes & No \\
\hline \multirow{3}{*}{ Influences } & $\begin{array}{l}\text { Did you ever find useful information } \\
\text { using your smartphone? }\end{array}$ & $\begin{array}{c}171 \\
(79.2)\end{array}$ & $\begin{array}{c}45 \\
(20.8)\end{array}$ \\
\hline & $\begin{array}{l}\text { Did you ever download useful and } \\
\text { educational application (apps) into your } \\
\text { smartphone? }\end{array}$ & $\begin{array}{c}142 \\
(65.7)\end{array}$ & $\begin{array}{c}74 \\
(34.3)\end{array}$ \\
\hline & $\begin{array}{l}\text { Did you ever discuss school projects } \\
\text { through chat messages in your } \\
\text { smartphones with your friends? }\end{array}$ & $\begin{array}{c}114 \\
(52.8)\end{array}$ & $\begin{array}{c}102 \\
(47.2)\end{array}$ \\
\hline \multirow{4}{*}{ Perception } & $\begin{array}{l}\text { Do you think smartphones is a } \\
\text { distraction tools when doing } \\
\text { homework? }\end{array}$ & $\begin{array}{c}129 \\
(59.7)\end{array}$ & $\begin{array}{c}87 \\
(40.3)\end{array}$ \\
\hline & $\begin{array}{l}\text { Do you think smartphones is a better } \\
\text { teaching tools than teachers? }\end{array}$ & $\begin{array}{c}70 \\
(32.4)\end{array}$ & $\begin{array}{c}146 \\
(67.6)\end{array}$ \\
\hline & $\begin{array}{l}\text { Do you think smartphones can cause } \\
\text { your academic result to decline? }\end{array}$ & $\begin{array}{c}151 \\
(69.9)\end{array}$ & $\begin{array}{c}65 \\
(30.1)\end{array}$ \\
\hline & $\begin{array}{l}\text { Do you think your school should ban } \\
\text { the smartphone use in your school } \\
\text { compound? }\end{array}$ & $\begin{array}{c}139 \\
(64.4)\end{array}$ & $\begin{array}{c}77 \\
(35.6)\end{array}$ \\
\hline
\end{tabular}

From the influences view, most of the respondents find smartphone as useful tool in getting information (79\%) and acknowledge that smartphone was useful for educational application (66\%).

From the perception view, the respondents understand that smartphone can cause a decline in their academic result. From the findings, 69.9\% agree it can cause decline in their academic result although 30.1\% disagree. More than half of the respondents (64.4\%) think that the smartphone should be ban in school but $35.6 \%$ disagree the statement.

When comparing the result, we found that the students are aware of the side effect of smartphone addiction on the academic result. This finding of this research is supported by the research of (al. L. K., 2015). They found that the use of smartphone has direct impact on the academic performance of higher learning students.

Table 4. Health Data

\begin{tabular}{|c|c|c|c|}
\hline \multirow[t]{2}{*}{ Types of Aspects } & \multirow{2}{*}{ Items } & \multicolumn{2}{|c|}{$\begin{array}{c}\text { Frequency (n) } \\
\text { Percentage (\%) }\end{array}$} \\
\hline & & Yes & No \\
\hline \multirow[t]{2}{*}{ Influences } & $\begin{array}{l}\text { Do you constantly have } \\
\text { pain on your thumb } \\
\text { after you use } \\
\text { smartphone? }\end{array}$ & $\begin{array}{c}70 \\
(32.4)\end{array}$ & $\begin{array}{c}146 \\
(67.6)\end{array}$ \\
\hline & Do you have headache & 110 & 106 \\
\hline
\end{tabular}




\begin{tabular}{|c|c|c|c|}
\hline & $\begin{array}{l}\text { after using smartphone } \\
\text { for a long period of } \\
\text { time? }\end{array}$ & (50.9) & $(49.1)$ \\
\hline & $\begin{array}{l}\text { Do you have blurry } \\
\text { vision after a long } \\
\text { period of using } \\
\text { smartphone? }\end{array}$ & $\begin{array}{c}82 \\
(38)\end{array}$ & $\begin{array}{l}134 \\
(62)\end{array}$ \\
\hline & $\begin{array}{l}\text { Do you have neck pain } \\
\text { after you using } \\
\text { smartphone while you } \\
\text { lied down? }\end{array}$ & $\begin{array}{c}123 \\
(56.9)\end{array}$ & $\begin{array}{c}93 \\
(43.1)\end{array}$ \\
\hline \multirow{3}{*}{ Perception } & $\begin{array}{l}\text { Do you think } \\
\text { smartphone is one of the } \\
\text { cause of obesity? }\end{array}$ & $\begin{array}{c}58 \\
(26.9)\end{array}$ & $\begin{array}{c}158 \\
(73.1)\end{array}$ \\
\hline & $\begin{array}{l}\text { Do you think } \\
\text { smartphone can emit } \\
\text { radiation? }\end{array}$ & $\begin{array}{c}145 \\
(67.1)\end{array}$ & $\begin{array}{c}71 \\
(32.9)\end{array}$ \\
\hline & $\begin{array}{l}\text { Do you think } \\
\text { smartphone can cause } \\
\text { wrist pain (carpal tunnel } \\
\text { syndrome)? }\end{array}$ & $\begin{array}{c}95 \\
(44)\end{array}$ & $\begin{array}{l}121 \\
(56)\end{array}$ \\
\hline
\end{tabular}

Many of the students (56.9\%), have neck pain after they used smartphone while they lied down but $43.1 \%$ disagree that they have neck pain. Their perception on smartphone is moderate when compare to the other two previous aspects. There are73.1\% of students population disagree with smartphone being a cause of obesity as it can relate to sedentary lifestyle. Meanwhile, $67.1 \%$ of the students agree that smartphone can emit radiation but 32.9\% disagree. Although long period usage of smartphone can cause wrist pain, but $56 \%$ of the school children disagree while $44 \%$ of them agree that smartphone can cause wrist pain. This study shows that the students are lacking in the knowledge of health issue regarding smartphone addiction as half of the participants disagreed with the opinion of obesity causes and carpal tunnel syndrome. This is contrary to the saying of professional such as consultant orthopedic surgeon Jonathan Dearing, spokesman for the Royal College of Surgeons of Edinburgh, which stated, technology revolution has led to reduced physical activity and obesity (Goldhill, 2015). Besides, (Dallas, 2014) wrote that carpal tunnel is one of the health problem of smart phone addiction.

\section{Conclusion}

The school children are not easily influence by smartphone and they have good perception on smartphone from the aspect of social behavior and from the academic performance.

The school children are not easily influence by smartphone and they have moderate perception on smartphone from the aspect of health.

\section{Recommendations}

The data showed a very positive outcome in this research, but the students still show lacking in the knowledge of the impact of smartphone on health. For that, we 
South American Journal of Academic Research

Volume 3, Issue 1, 2016

can overcome it by having seminars or talks in the primary school where the information of the harms of smartphone would be discuss.

Nevertheless, every coins have two sides; smartphone can bring certain advantages to this e-generation. For instance, students can learn better with the aid of smartphone. Plus, there are a lot of information on the internet where we can't learn from the textbook; hence exploring the children to the wonderful things in this world. In addition to it, having a smartphone can shaped the child to be a more responsible and discipline individual as they have to control their time and desire.

\section{References}

[1]. al, B. K. (2011). Mobile phones bridging the digital divide for teens in the US?. Future Internet., 144-158.

[2]. al, C. e. (2011, January 02). Extending family to school Life: college students' use of mobile phone. Retrieved from allacademic research: http://citation.allacademic.com/meta/p_mla_apa_research_citation/1/7/1/0/1/p171018_index.html

[3]. al, D.-D. J. (2008/2009). Screen media time use of 12-16 year-old Spanish school adolescents: effects of personal and socioeconomic factors, season and type of day. Journal of Adolescence, 213231.

[4]. al, m. h. (2011). The impact of cell phone use on social networking and development among college student. The American Association of Behavioral and Social Sciences., 20.

[5]. al., L. K. (2015). Smartphones’ Effects on Academic Performance. Journal of Multidisciplinary Engineering Science and Technology, 5-6.

[6]. al., T. S. (2003). Mobile, Youth culture, shaping telephone use in Australia and Singapore. ANZCA03 Australian and New Zealand Communication Association. Brisbane, Queensland.

[7]. Archer, D. (2013, july 25). Smartphone addiction. Retrieved from Psychology today: http://www.psychologytoday.com/blog/reading-between-the-headlines/201307/smartphone-addiction

[8]. B, C. (1997). Community and consumption: towards a definition of the 'linking value' of product or services. 31, 297-316.

[9]. Boscamp, E. (2015, May 18). mindbodygreen. Retrieved from How Smartphones Affect Your Kids' Academic Performance: http://www.mindbodygreen.com/0-18789/how-smartphones-affect-yourkids-academic-performance.html

[10]. Dallas, K. (2014, November 22). 4 unexpected health risks of smartphone use. Retrieved from Deseret News National: http://national.deseretnews.com/article/2841/4-unexpected-health-risks-ofsmartphone-use.html

[11]. EJ, A. K. (2003). An analysis of young people's use of and attitudes toward cell phones. telemat info, 20: 349-364.

[12]. Goldhill, O. (2015, April 13). Why smartphones are making you ill. Retrieved from The Telegraph: http://www.telegraph.co.uk/technology/news/11532428/Why-smartphones-are-makingyou-ill.html

[13]. Griffiths M, R. B. (2003). Misfortune or Mismanagement: A study of consumer debt issues. Ourimbah, Australia.

[14]. GrowingWireless. (n.d.). Kids Wireless Use Facts. Retrieved from growingwireless: http://www.growingwireless.com/get-the-facts/quick-facts

[15]. Jacobsen, W. a. (2011). The wired generation: Academic and social outcomes of electronic media use aming university students. cyber psychology, behavior, and social networking, 275-280.

[16]. James J, D. J. (2011, January 21). Exploring addictive consumption of mobile phone technology. Retrieved from ANZMAC 2005 Conference: Electronic Marketing: http://smib.vuw.ac.nz:8081/WWW/ANZMAC2005/cd- site/pdfs/12

[17]. Jones, R. (2013, November 12). 5 Benefits of Giving Your Kids a Smartphone. Retrieved from eduPad: http://www.edupad.com/blog/2013/11/5-benefits-giving-kids-smartphone/

[18]. Junco, R. (2012). The relationship betwen frequency of Facebook use, participation in Facebook activities, and student engagement. Computer and Education, 162-171.

[19]. Junco, R. (2012). Too much face and not enough books: the relationship between multiple indices of facebook use and academic performance. Computers in Human Behaviour, 187-198. 
[20]. Junco, R. a. (2012). No A 4 U: The relationship between multitasking and academic performace. Computers and education, 505-514.

[21]. Krumboltz, M. (2013, October 28). Study: 38 percent of kids under 2 use smartphones or tablets. Retrieved from Yahoo News: http://news.yahoo.com/blogs/sideshow/38--of-kids-under-2-usesmartphones-or-tablets--study-212548190.html

[22]. L, S. (2005). Mobile phones and evolution of social behaviour. Info Technol, 24, 111-129.

[23]. Lunden, I. (2015, June 2). 6.1B Smartphone Users Globally By 2020, Overtaking Basic Fixed Phone Subscriptions. Retrieved from techcrunch: http://techcrunch.com/2015/06/02/6-1b-smartphoneusers-globally-by-2020-overtaking-basic-fixed-phone-subscriptions/\#.4zldejn:RPIH

[24]. Meredith, L. (2012, December 16). D News. Retrieved from Cellphones Are Changing School Emergency Plans: http://news.discovery.com/tech/cellphones-changing-school-emergency-plans121216.htm

[25]. Min Kwon, D.-J. K. (2013, December 31). The Smartphone Addiction Scale: Development and. Retrieved from Open Access: http://www.plosone.org/article/fetchObject.action?uri=info:doi/10.1371/journal.pone.0083558\&represe ntation=PDF

[26]. Pew Research Center. (n.d.). Mobile Technology Fact Sheet. Retrieved from pewinternet: http://www.pewinternet.org/fact-sheets/mobile-technology-fact-sheet/

[27]. Power MR, H. L. (2004). Keeping and supporting relationship through SMS text messaging.

[28]. R, M. (n.d.). The Psychosocial Aspects of Mobile Phone Use Among Adolescents. In Psych, 26: 16-19.

[29]. Sánchez-Martínez, M. a. (2009). Factor associated with cell phone use in adolescents in the community of Madrid (Spain). Cyber Psychology and Behavior, 131-137.

[30]. Thompson R, R. G. (2007). more safely for children with mobiles. card technology today, 19(9): 10.

[31]. U, N. (2008). Addiction with internet and mobile. An overiew. J. Pakistan Psychiatric soc, 72.

[32]. V, F. (2000). ICT in the rush hour of life. 16: 65-75.

[33]. W, T. D. (2012). The use and abse of cell phones and text messaging in the classroom. College Teaching, 1-9.

[34]. Wood, E. Z. (2012). Examining the impact of off-task multitasking with technology on real time classroom learning. Computers and Education, 365-374. 